\title{
Kelola
}

\section{ALTERNATIF STRATEGI PENINGKATAN DAYA SAING SMA KRISTEN 2 SALATIGA}

\author{
Innes Septa Nindiarini \\ Alumni Program Studi Magister Manajemen Pendidikan \\ FKIP-Universitas Kristen Satya Wacana \\ innes.septa@gmail.com \\ Bambang S. Sulasmono \\ Program Studi Magister Manajemen Pendidikan \\ FKIP-Universitas Kristen Satya Wacana \\ bambang.sulasmono@staff.uksw.edu
}

\begin{abstract}
This research and development aims to formulate strategic plan to enhancing competitiveness in SMA Kristen 2 Salatiga. Data were gathered by means of Focus Group Discussion (FGD), interview, questionnaire, and documentation study. Fishbone analysis is used to identify the root causes of low school competitiveness. The analysis was categorized based on five factors i.e. reputation, school resources, information and technology, human resource, and partnership. Based on the analysis, the strategies are formulated with educational reengineering approach as follows: 1) reconstructing school image by improving academic and non academic achievement, 2) developing innovative curriculum based on outdoor experience and IT, 3) increasing student discipline, 4) optimizing IT usage on promotion and marketing, 5) improving the quality of school programs, 6) developing entrepreneurship programs, 7) improving the quantity and quality school infrastructures, 8) improving teachers' skill and competence of IT, 9) enhancing the role of school board, 10) maximizing the role of parents, alumnae, and other institution to develop the school programs, and 11) establishing a vocational high school. It is recommended for the school to have cooperation with the stakeholder and the school board to implement the strategic plan so that the competitiveness will enhance in the future.
\end{abstract}

Keywords: Strategy, Competitiveness, Fishbone Analysis, Educational Reengineering 


\section{PENDAHULUAN}

Globalisasi merupakan isu besar yang diidentikkan dengan inovasi dan perkembangan di bidang teknologi dan informasi yang berdampak pada meningkatnya iklim kompetisi dalam masyarakat (Ogrean \& Herciu, 2010). Kompetisi sebagai dampak perkembangan di bidang teknologi dan informasi tersebut tidak terbatas pada sektor ekonomi namun juga pada sektor pendidikan. Kompetisi di sektor pendidikan diartikan sebagai usaha yang dilakukan sekolah untuk memenuhi permintaan konsumen dengan menciptakan sekolah yang berkualitas tinggi dan menghasilkan lulusan yang berprestasi (Belfield \& Levin, 2002) untuk mampu bertahan di tengah kompetisi, sekolah harus memiliki daya saing. Daya saing tinggi diperlukan sekolah agar mampu mempertahankan eksistensinya di tengah persaingan antar sekolah yang kompetitif. Salah satu indikator bahwa sekolah memilikidaya saingtinggi adalah tingginyatingkat kepercayaan konsumen yang tercermin dalam jumlah penerimaan siswa(Belfield \&Levin, 2002)

Marginson \& Wende (2007) menghubungkan istilah daya saing dalam bidang pendidikan dengan kata keunggulan, reputasi, dan status. Dalam bidang pendidikan dan bisnis, daya saing sama-sama diartikan sebagai menjadi lebih baik atau unik, memiliki reputasi yang baik, meningkatnya jumlah pelanggan (siswa), dikenal oleh masyarakat, dan memiliki jaringan yang luas (Haan \& Yan, 2013). Melalui penelitian yang dilakukan di beberapa institusi pendidikan dan universitas di Belanda, Haan dan Yan menarik suatu pemahaman bahwa daya saing dalam sektor pendidikan tergantung pada perbaikan dan peningkatan nilai internal yang ditentukan oleh penilaian eksternal, seperti pertumbuhan jumlah dan besaran siswa, peningkatan peringkat, perolehan prestasi, dan lain sebagainya.
Daya saing yang dimiliki oleh sekolah dipengaruhi oleh beberapa faktor yang sangat penting bagi terciptanya daya saing yang sustainable bagi sekolah. Faktor tersebut antara lain:

\section{a. Reputasi}

Reputasi berpengaruh terhadap pembentukan daya saing institusi (DeNisi, A. S., Hitt, M. A., \& Jackson, 2003). Casidy, (2013) menyatakan bahwa reputasi adalah penilaian terhadap kualitas institusi yang terbentuk karena adanya konsistensi kualitas yang ditunjukkan oleh institusi tersebut. Reputasi kuat merupakan salah satu kompetensi kunci bagi institusi pendidikan untuk sukses bersaing dalam persaingan global (Mazzarol dan Soutar dalam Casidy, 2013). Reputasi sekolah dapat dapat dibentuk oleh faktor fisik seperti lokasi (Chapleo, 2010) serta layanan yang ditawarkan oleh sekolah tersebut.

\section{b. Sumber Daya Sekolah}

Sumber daya sekolah diasosiasikan dengan program sekolah dan finansial (Carter dalam Depperu, D., \& Cerrato, 2005; Kazlauskaite, R., $\&$ Buciuniene, 2008). Salah satu cara sekolah dalam menciptakan sumber daya yang mampu menciptakan daya saingtinggi adalah kemampuan sekolah untuk menciptakan program sekolah yang memiliki sifat inimitable (sukar ditiru). Program yang bersifat inimitable tersebut adalah salah satu faktor potensial yang menjadikan institusi memiliki daya saing (Srivastava, R. K., Fahey, L., \& Christensen, 2001). Hal lain yang menjadi faktor pembentuk daya saing adalah faktor finansial (Kazlauskaite, R., \& Buciuniene, 2008). Untuk menciptakan program sekolah yang bersifat inimitable serta mendukung terlaksananya program, sekolah memerlukan ketercukupan secara finansial. Ketersediaan finansial sangat mendukung berjalannya kegiatan dan program sekolah. 


\section{c. Teknologi Informasi}

Teknologi informasi menjadi faktor potensial yang mendukung keunggulan daya saing (Rohrbeck, 2010). Penggunaan TI dalam proses pembelajaran dapat meningkatkan kualitas hasil pembelajaran (Tinio, 2003). Tamandl \& Nagy (2013) menyatakan bahwa kualitas hasil pembelajaran siswa menjadi salah satu faktor bagaimana daya saing sekolah terbentuk. Penggunaan teknologi informasi sebagai faktor pembentuk daya saing tidak terbatas pada manajemen pembelajaran tetapi meluas pada penggunaan TI pada manajemen informasi di sekolah. Penggunaan teknologi informasi tersebut menjadikan sistem manajemen di institusi pendidikan menjadi lebih fleksibel dan efisien dalam segi waktu dan biaya (Tagalou, Massourou, \& Kuriakopoulou, 2013; Tamandl \& Nagy, 2013).

\section{d. Sumber Daya Manusia}

Sumber daya manusia dalam institusi merupakan salah satu faktor potensial yang penting dalam keunggulan daya saing (Rahayu, 2010). Menurut Rahayu, kesesuaian kualifikasi akademik tenaga pendidik dan kependidikan, jumlah tenaga pendidik bersertifikasi, serta keahlian tenaga kependidikan merupakan faktor penting untuk mencapai daya saing sekolah yang berkelanjutan. Pernyataan Rahayu tersebut didukung oleh penelitian yang dilakukan oleh Krismawintari (2011) yang menunjukkan bahwa tenaga pendidik yang memiliki kompetensi dan softskill menjadi faktor yang mempengaruhi orang tua dalam memilih sekolah.

\section{e. Kemitraan}

Beberapa studi literatur menyatakan bahwa kemitraan merupakan salah satu faktor keunggulan daya saing bagi institusi (Ireland, Hitt, \& Vaidyanath, 2002; Trim, 2003).
Kemitraan sekolah dengan pemerintah, institusi pendidikan sejawat, serta lembaga lain yang dapat dipergunakan untuk pengembangan sekolah tersebut. Disamping hal tersebut, Halal (dalam Binsardi \& Ekwulugo, 2003) juga menambahkan bahwa hubungan sekolah dengan pelanggan, seperti orang tua, perwakilan masyarakat, pemerintah, dan penyandang dana merupakan hal yang penting. Breen \& Hing (2012) menjelaskan beberapa keuntungan utama yang didapat oleh pihak sekolah melalui kemitraan dengan institusi lain atau pihak lain adalah sekolah dapat menambah daya jual melalui program yang ditawarkan, meningkatkan reputasi sekolah, mendapatkan bantuan dana untuk pengembangan sekolah, dan meningkatkan skala ekonomi atau keadaan finansial sekolah.

Untuk meningkatkan daya saing, sekolah memerlukan strategi. Hamel dan Prahalad (dalam Crainer \& Dearlove, 2014) mendefinisikan strategi sebagai sebuah latihan memposisikan pilihan-pilihan institusi yang akan diuji dengan bagaimana pilihan tersebut sesuai dengan struktur yang telah ada. Proses perumusan strategi yang dilakukan oleh sekolah sering disebut juga sebagai perencanaan strategis sekolah. Sedangkan produk dari perencanaan strategis sekolah pada umumnya dituangkan kedalam bentuk dokumen yang dinamakan rencana strategis.

Rencana strategis merupakan sebuah dokumen yang berisi tentang rencana institusi dalam mencapai misinya(Gates, 2010). Dalam konteks sekolah, rencana strategis merupakan rencana sekolah untuk mencapai tujuan yang hendak dicapai. Rencana strategis sekolah merupakan sebuah fondasi yang dimiliki sekolah yang berisi mengenai hal-hal apa saja yang harus dilakukan sekolah dalam jangka waktu tertentu. 
Beberapa literatur tentang manajemen strategis membahas tentang strategi yang dapat digunakan untuk meraih keunggulan daya saing. Strategi yang dapat digunakan adalah strategi kompetitif dan strategi kooperatif(Rahayu, 2010). Porter (dalam Crainer \& Dearlove, 2014) memperkenalkan salah satu konsep strategi kompetitif yang disebut dengan strategi generik, yang meliputi tiga strategi yaitu diferensiasi, biaya, dan fokus. Strategi diferensiasi menekankan pada aspek penawaran lebih, berupa kualitas, pelayanan, dan sarana khusus. Strategi biaya menekankan pada penawaran produk dan jasa dengan biaya terendah. Pada strategi fokus menekankan penawaran produk atau jasanya terhadap kelompok pelanggan potensial tertentu. Sedangkan strategi kooperatif untuk meraih keunggulan daya saing berfokus pada perluasan jaringan kemitraan (partnership) dengan institusi lain.

Di samping itu dikenal juga strategi rekayasa ulang pendidikan. Rekayasa ulang pendidikan adalah kerangka kerja konseptual bagi pendidik untuk memikirkan dan menilai kembali sistem penyampaian pendidikan yang sedang berlangsung untuk kemudian disesuaikan dengan permintaan ekonomi global yang menuntut tersedianya produk pendidikan berkualitas serta jaringan kerjasama yang saling bergantung satu sama lain (Weller dalam Tunç, 2013). Rekayasa ulang pendidikan memampukan sekolah untuk menentukan langkah perubahan yang dibutuhkan secara mendasar dan membawa perbaikan sehingga pada akhir-nya mampu bertahan dan unggul dalam kompetisi. Tujuan Rekayasa Ulang Pendidikan ada-lah untuk meningkatkan efektifitas dan efisiensi berbagai aktivitas pendidikan (Sprawls, n.d.; Tunç, 2013).

Rekayasa ulang pendidikan merupakan salah satu pendekatan yang direkomendasikan untuk institusi pendidikan agar lebih memilikidaya saing yang kompetitif(Tunç, 2013). Danim(2006) mengemukakan tiga faktor yang mendasari Rekayasa Ulang Pendidikan, yaitu pelangan, kompetisi, dan perubahan. Dalam implementasi Rekayasa Ulang Pendidikan, Ahmad \& Francis (2007) menekankan tujuh faktor penting yang perlu diperhatikan yaitu 1) kultur kerjasama antar karyawan dan kulturyang berorientasi pada mutu; 2) sistem manajemen mutu melalui perbaikan berkelanjutan dan pemberian penghargaan/insentif terhadap karyawan; 3) manajemen perubahan; 4) pengurangan birokrasi untuk menciptakan manajemen yang partisipatif sehingga mendorong munculnya inovasi;5) teknologi informasi/sistem informasi yang berfungsi untuk meningkatkan kecepatan proses, meminimalisir kesalahan, dan meningkatkan efektfitas; 6) manajemen program, dengan mempertimbangkan seluruh aspek pendukung yang didokumentasikan melalui rencana program; dan 7) ketercukupan dana.

Persaingan antar sekolah di Indonesia dewasa ini menjadi lebih kompetitif sebagai salah satu akibat dari otonomi yang diberikan pemerintah kepada masyarakat perihal kebijakan pendirian sekolah (Rahayu, 2010). Kebijakan tersebut mendorong beragam sekolah baru bermunculan yang semakin memperketat persaingan antar sekolah. Seiring dengan kebijakan tersebut, Kota Salatiga mengalami pertumbuhan perihal jumlah sekolah dalam kurun waktu tujuh tahun (2007-2014).

Berdasarkan data dari BPS Kota Salatiga tahun 2011 dan data dari Dinas Pendidikan Kota Salatigatahun 2014, jumlah sekolah di jenjang sekolah dasar sampai dengan sekolah menengah atas mengalami peningkatan. Khusus pada jenjang sekolah menengah atas, jumlah sekolah pada tahun 2007 adalah 28 sekolah dan menjadi 33 sekolah pada tahun 2014. Dengan semakin banyaknya jumlah sekolah di Salatiga, persaingan sekolah untuk mendapatkan siswa baru semakin kompetitif. Data dari Dinas Pendidikan Kota Salatiga (2014) tentang 
Penerimaan Peserta Didik Baru (PPDB) Online tahun ajaran 2013/2014 dan 2014/2015, tiga sekolah yang bersaing yaitu SMA Negeri 1 , SMA Negeri 2, dan SMA Negeri 3 selalu dapat memenuhi kuota daya tampung masing-masing sekolah. Namun keberhasilan SMA Negeri di Salatiga dalam mencapai kuota maksimal PPDB tersebut tidak terjadi pada beberapa SMA Swasta di Salatiga. Salah satu sekolah tersebut adalah SMA Kristen 2 Salatiga. SMA swasta yang telah berdiri sejak tahun 1982 tersebut selama kurun waktu 2010 s/d 2015 memiliki jumlah siswa baru terus menurun sebagaimana tergambar dalam Tabel 1 berikut ini.

\section{METODE PENELITIAN}

Penelitian ini merupakan penelitian pengembangan. Desain penelitian pengembangan mengadaptasi model penelitian dan pengembangan oleh Sugiyono (2009) yang terdiri dari 10 tahap, namun hanya dilakukan secara terbatas sampai pada tahap revisi desain produk rencana strategis SMA Kristen 2 Salatiga. Kelima tahapan yang dilakukan adalah (1) Potensi dan masalah, (2) Pengumpulan data, (3) Desain produk, (4) Validasi desain,(5) Revisi desain.

Pengumpulan data dilakukan melalui wawancara, kuesioner, Focus Group Discussion (FGD), dan studi dokumentasi. Subjek

Tabel 1 Jumlah Penerimaan Siswa Baru SMA Kr 2 Salatiga Tahun 2010/2011 s/d 2014/2015

\begin{tabular}{ccc}
\hline Tahun Ajaran & Siswa yang mendaftar & $\begin{array}{c}\text { Siswa yang melakukan } \\
\text { daftar ulang }\end{array}$ \\
\hline $2010 / 2011$ & 30 & 26 \\
$2011 / 2012$ & 42 & 39 \\
$2012 / 2013$ & 35 & 30 \\
$2013 / 2014$ & 29 & 26 \\
$2014 / 2015$ & 22 & 16 \\
\hline
\end{tabular}

Sumber: Data Sekolah, 2014

Tabel 1 menggambarkan permasalahan yang dihadapi SMA Kristen 2 Salatiga berkaitan jumlah siswa baru. Penurunan terjadi dari tahun ke tahun dan pada tahun ajaran 2014/ 2015 ini, jumlah siswa baru yang melakukan daftar ulang hanya berjumlah 16 siswa baru. Ditinjau dari indikator daya saing sekolah terkait input siswa, rendahnya jumlah penerimaan siswabaru di SMA Kristen 2 menunjukkan bahwa daya saing SMA Kristen 2 Salatiga rendah. Berdasarkan latar belakang masalah tersebut, penelitian ini bertujuan untuk menganalisis akar permasalahan rendahnya daya saing SMA Kristen 2 Salatiga dan menghasilkan alternatif strategi berupa rencana strategis peningkatan daya saing SMA Kristen 2 Salatiga. penelitian adalah kepala sekolah, wakil kepala sekolah, bendahara sekolah, guru, ketua komite sekolah, siswa, dan orang tua siswa. Studi dokumentasi dilakukan pada beberapa dokumen tertulis antara lain profil sekolah, rencana strategi sekolah, program kerja sekolah, data guru dan karyawan, data siswa, serta prestasi akademik dan non akademik sekolah. Uji kredibilitas terhadap data yang diperoleh dilakukan dengan teknik trianggulasi sumber dan trianggulasi teknik.

\section{HASIL PENELITIANDANPEMBAHASAN}

\section{Akar Permasalahan}

Hasil analisis melalui diagram fishbone menunjukkan beberapa akar permasalahan yang menyebabkan rendahnya daya saing SMA Kristen 2 Salatiga: 


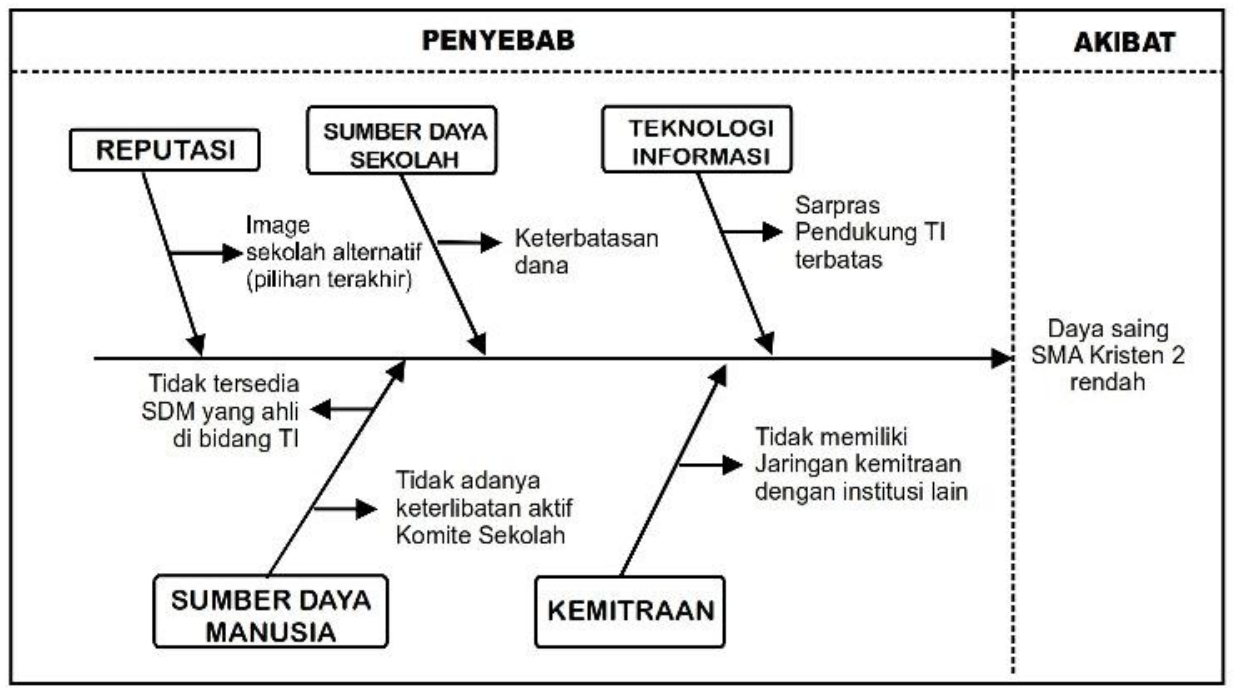

Gambar 1 Diagram Fishbone Rendahnya Daya Saing SMA Kristen 2 Salatiga

Akar permasalahan yang diidentifikasi melalui FGD dalam faktor reputasi sekolah adalah image sekolah non unggulan atau sekolah pilihan terakhir bagi masyarakat. Melalui hasil kuesioner terhadap 56 siswa, $46 \%$ persen siswa menyatakan bahwa SMA Kristen 2 Salatiga merupakan pilihan terakhir mereka setelah tidak diterima di SMA/SMK lain. Sedangkan berdasarkan hasil wawancara, image sekolah alternatif terbentuk berdasarkan penilaian masyarakat terhadap sekolah terkait dengan faktor siswa dan lokasi sekolah. Judson, et al (dalam Casidy, 2013) menyatakan bahwa reputasi sekolah merupakan faktor penting yang sangat berpengaruh dalam pemasaran sekolah.

Akar permasalahan pada faktor sumber daya sekolah adalah keterbatasan dana. Ketercukupan dana merupakan salah satu faktor pendukung yang menciptakan daya saing (Kazlauskaite, R., \& Buciuniene, 2008). Dalam proses brainstorming FGD, terbatasnya dana menghambat kegiatan sekolah, salah satunya dalam mendukung program kegiatan esktrakurikuler. Biaya yang harus dikeluarkan sekolah dalam menyelenggarakan kegiatan ekstrakurikuler seperti biaya guru pendamping, sewa tempat, dan biaya yang dikeluarkan sekolah rusak dan tidak tersedianya akses internet bagi siswa di sekolah. Berdasarkan hasil brainstorming FGD, jaringan internet telah tersedia di sekolah sebagai bantuan dari pemerintah namun penggunaannya masih sangat terbatas karena terbatasnya sarana prasarana.

Akar permasalahan pada faktor sumber daya manusia adalah tidak tersedia SDM yang ahli di bidang TI dan tidak adanya keterlibatan aktif komite sekolah. Kompetensi dan keahlian guru dan staf menjadi salah satu faktor penting dalam menciptakan daya saing sekolah (Rahayu, 2010). Berdasarkan hasil penelitian, keterampilan guru, tenaga administrasi dan kependidikan di bidang TI di SMA Kristen 2 saat ini masih terbatas. Akar permasalahan lain adalah tidak berfungsinya komite sekolah. Komite sekolah berperan untuk mendorong terwujudnya penyelenggaraan pendidikan yang berkualitas melalui perannya dalam tahap perencanaan, implementasi, dan evaluasi program sekolah (Tjuana, 2012). Berdasarkan hasil penelitian, kepengurusan komite sekolah sudah terbentuk, namun dalam pelaksanaannya sangat pasif.

Akar permasalahan yang menyebabkan daya saing SMA Kristen 2 Salatiga rendah 
dalam faktor kemitraan adalah tidak adanya jaringan kemitraan dengan lembaga lain. Trim (2003) menyatakan bahwa kemitraan penting bagi sekolah untuk memperluas jangkauan, membuka akses untuk kemajuan sekolah, menjaring calon pelanggan, dan mendorong kemandirian sekolah di tengah persaingan. SMA Kristen 2Salatiga belum memiliki jaringan kemitraan dengan pihak atau lembaga manapun. Hal ini diakui sekolah karena sekolah belum merasa percaya diri dengan prestasi dan kemampuan sekolah dalam menawarkan hubungan kerjasama.

\section{Rencana Strategis Peningkatan Daya Saing SMA Kristen 2 Salatiga}

Rencana strategis (renstra) peningkatan daya saing SMA Kristen 2 Salatiga dirumuskan menggunakan pendekatan rekayasa ulang pendidikan. Renstra dikelompokkan dalam empat bidang yaitu Kurikulum, Kesiswaan, Humas, dan Sarana Prasarana.

Strategi yang dirumuskan untuk peningkatan daya saing di bidang Kurikulum meliputi: 1) rekonstruksi reputasi sekolah melalui peningkatan prestasi akademik dan non akademik, 2) mengembangkan kurikulum yang inovatif, berbasis pengalaman dengan dunia luar dan TI, dan 3) peningkatan kemampuan dan keahlian guru dan tenaga kependidikan di bidang TI. Rekonstruksi image atau reputasi sekolah melalui peningkatan prestasi akademik dan non akademik merupakan strategi yang disarankan untuk memperbaiki reputasi sekolah yang selama ini melekat sebagai sekolah non unggulan. Kebutuhan pelanggan atas kualitas pendidikan merupakan salah satu hal yang mendasari praktek rekayasa ulang pendidikan di sekolah (Danim, 2006). Sekolah juga dapat meningkatkan standar akademis dan non akademis sebagai langkah awal untuk meningkatkan kualitas output siswa yang dihasilkan.
Strategi lain yang disarankan adalah mengembangkan kurikulum yang inovatif, berbasis pengalaman dengan dunia luar dan TI. Program dapat dilaksanakan melalui kegiatan pembelajaran dengan melibatkan masyarakat seperti live in dan company visit. Penggunaan TI dalam pembelajaran merupakan hal yang penting untuk diimplementasikan di era digital seperti saat ini. Penggunaan teknologi dapat menambah motivasi belajar siswa dan merubah suasana kelas menjadi lebih menyenangkan dalam proses pembelajaran (Hawkins, 2002).

Strategi lain yang disarankan dalam bidang kurikulum adalah peningkatan kemampuan dan keahlian guru dan tenaga kependidikan di bidang TI. Sprawls (nd) menekankan beberapa poin penting dalam rekayasa ulang pendidikan yang salah satunya adalah pentingnya memberikan kesempatan bagi guru untuk belajar dan mengembangkan diri dalam penggunaan TI di sekolah.

Strategi peningkatan daya saing bidang kesiswaan adalah 1) meningkatkan kualitas pelaksanaan program kegiatan sekolah, 2) meningkatkan kedisiplinan siswa, dan 3) menyusun program kewirausahaan sekolah. Strategi pertama dalam bidang kesiswaan adalah meningkatkan kualitas pelaksanaan program kegiatan sekolah. Program kegiatan yang menjadi fokus dalam bidang kesiswaan adalah kegiatan ekstrakurikuler. Menurut Bosetti (2004), program ekstrakurikuler merupakan salah satu program kegiatan sekolah yang dapat menjadi daya tarik. Berdasarkan hal tersebut, kualitas program kegiatan ekstrakurikuler di SMA Kristen 2 Salatiga harus ditingkatkan melalui penyelenggaraan kegiatan ekstrakurikuler secara rutin dan terprogram, menambah variasi program ekstrakurikuler sesuai minat siswa contohnya ekskul seni dan musik, dan menjalin kemitraan dengan institusi lain, seperti sekolah sepakbola untuk meningkatkan kualitas ekskul 
sepakbola dan futsal yang selama ini menjadi ekskul unggulan.

Strategi kedua dalam bidang kesiswaan adalah peningkatan kedisiplinan siswa dengan memperketat pelaksanaan tata tertib siswa. Peningkatan kedisiplinan melalui penegakan tata tertib juga merupakan upaya dalam rekonstruksi reputasi sekolah dan peningkatan kualitas lulusan sekolah.

Strategi ketiga dalam bidang kesiswaan adalah menyusun program kewirausahaan sekolah. Program yang diusulkan meliputi program bank sampah yaitu pengolahan pupuk kompos dan program daur ulang, serta program budidaya jamur. Kondisi lingkungan sekolah yang didukung dengan area terbuka hijau yang cukup luas diharapkan dapat mendukung pemberdayaan program-program kewirausahaan bagi siswa di sekolah. Menurut Hakim (2012) pendidikan kewirausahaan merupakan salah satu aspek penting dan strategis untuk meningkatkan daya saing yang dapat diimplementasikan secara terpadu dalam kegiatankegiatan pendidikan di sekolah.

Strategi yang disarankan dalam bidang Humas meliputi: 1) meningkatkan penggunaan TI dalam program promosi dan pemasaran sekolah, 2) memaksimalkan peran orang tua siswa, jaringan alumni, dan lembaga lain untuk pengembangan program kegiatan sekolah, 3) meningkatkan peran dan fungsi Komite Sekolah, dan 4) mengganti SMA menjadi SMK. Integrasi teknologi informasi dalam sistem manajemen sekolah menjadikan sekolah menjadi lebih fleksibel dan efisien dalam segi waktu dan biaya (Tamandl \& Nagy, 2013). Pemanfaatan kecanggihan di bidang teknologi dan informasi merupakan salah satu strategi yang dapat digunakan dalam rekayasa ulang pendidikan. Media sosial seperti Facebook merupakan sarana yang dapat digunakan oleh sekolah dalam program promosi. Penggunaan SMS
Gateaway juga dapat digunakan untuk meningkatkan program promosi dan pemasaran kepada target pelanggan. SMS Gateaway merupakan perangkat komunikasi

Hasil analisis akan permasalahan yang dapat digunakan sekolah untuk memberikan informasi kepada calon orang tua/wali siswa melalui pengiriman pesan singkat. Program SMS Gateaway dapat diunduh dengan gratis dengan biaya operasional yang ekonomis.

Strategi lain dalam bidang Humas adalah memaksimalkan peran orang tua siswa, jaringan alumni, dan lembaga lain untuk pengembangan program kegiatan sekolah. Chiepe (dalam Danim, 2006) menyatakan bahwa partisipasi masyarakat dan orang tua siswa dibutuhkan dalam implementasi rekayasa ulang pendidikan untuk peningkatan kualitas pendidikan. Strategi kooperatif melalui jalinan kerjasama dibutuhkan dalam upaya meningkatkan daya saing sekolah (Rahayu, 2010). Program yang dirumuskan untuk meningkatkan keterlibatan orang tua siswa antara lain mengadakan pertemuan orang tua murid dengan wali kelas setiap satu semester dan menyelenggarakan seminar pendidikan dengan melibatkan orang tua siswa. Untuk meningkatkan keterlibatan alumni sekolah dapat membentuk forum alumni dan menjalin hubungan secara aktif. Penggunaan media sosial juga dapat digunakan untuk menghimpun para alumni. Peningkatan keterlibatan dengan institusi lain dapat dilakukan dengan kampus UKSW melalui program kemitraan dengan Fakultas TI dalam penerimaan mahasiswa kerja praktek, kemitraan dengan gereja sebagai sarana promosi melalui pelayanan grup vokal siswa di gereja, dan kemitraan dengan SMP, Bimbingan Belajar, dan pemerintah melalui Kejar Paket B dalam program promosi sekolah.

Strategi lain dalam bidang Humas adalah meningkatkan peran dan fungsi Komite 
Sekolah. Keberadaan dan peran komite sekolah berperan penting dalam peningkatan kualitas pendidikan di sekolah yang menjadi salah satu hal yang mendukung terbentuknya daya saing pendidikan (Tjuana, 2012). Program yang dirumuskan adalah mengadakan pertemuan rutin dengan Komite sekolah setiap semester guna melakukan koordinasi yang diperlukan dalam mengupayakan kemajuan sekolah.

Strategi lain dalam bidang humas adalah mengganti SMA dengan SMK. Sekolah melalui bidang Humas dapat menjalin komunikasi dan melibatkan pihak yayasan dan komite sekolah dalam pembahasan wacana penggantian SMA menjadi SMK. Pendirian SMK juga dipertimbangkan mengingat pada akhir tahun 2015 Indonesia akan tergabung dalam Masyarakat Ekonomi ASEAN(MEA). Untuk menghadapi tantangan tersebut maka pemerintah Indonesia mengeluarkan kebijakan di bidang tenaga kerja dengan meningkatkan kualitas SDM yang produktif dan terampil melalui lulusan SMK yang memiliki sertifikasi keahlian internasional (Rahman, 2015; Utomo, 2014). Melihat peluang di masa depan akan kebutuhan masyarakat akan pendidikan yang menghasilkan lulusan yang produktif dan berkeahlian melalui lulusan SMK, maka pihak internal sekolah dapat mempertimbangkan untuk mengganti SMA dengan SMK.

Strategi bidang sarana prasarana untuk meningkatkan daya saing sekolah adalah meningkatkan kualitas dan kuantitas sarana dan prasarana berbasis TI secara bertahap. Salah satu hal yang disarankan dalam rekayasa ulang pendidikan adalah penggunaan teknologi informasi di sekolah (Gross, 2004; Sprawls, n.d.). Penggunaan sarana prasarana berbasis TI di sekolah dapat digunakan untuk pengembangan bahan pendidikan, komunikasi, manajemen informasi, dan pengelolaan pendidikan. Berdasarkan hasil kuesioner terhadap siswa, mayoritas siswa berpendapat bahwa penggunaan dan kualitas perangkat TI di sekolah, seperti LCD dan komputer, masih minim dan perlu adanya perbaikan dan penambahan dalam segi kualitas dan kuantitas. Berdasarkan hal tersebut, perbaikan kualitas komputer di sekolah dengan memperbaiki komputer, meng-upgrade aplikasi komputer dan penambahan LCD sebaiknya dilakukan secara berkala. Disamping itu, penyediaan internet bagi siswa di sekolah juga diperlukan. Sekolah telah mendapat bantuan akses internet dari pemerintah. Namun berdasarkan hasil kuesioner pada siswa, penggunaan internet terbatas. Oleh karena itu, sekolah perlu membuka akses internet bagi siswa agar dapat digunakan untuk menunjang aktivitas pembelajaran siswa. Akses internet terhadap siswa tersebut tentunya juga harus diimbangi dengan pengawasan melalui pemblokiran akses terhadap situs dan konten yang tidak mendukung proses pembelajaran.

\section{SIMPULAN DAN SARAN}

\section{Simpulan}

Hasil analisis akar permasalahan ditinjau dari faktor reputasi sekolah adalah image sekolah non unggulan, sedangkan hasil analisis akar permasalahan pada faktor sumber daya sekolah adalah keterbatasan dana. Pada faktor teknologi informasi, akar permasalahan yang diidentifikasi adalah sarana prasarana penunjang di bidang TI terbatas. Sedangkan pada faktor sumber daya manusia, akar permasalahan yang diidentifikasi adalah tidak tersedia SDM yang ahli di bidang TI dan tidak adanya keterlibatan dari Komite Sekolah. Pada faktor kemitraan, akar permasalahan yang diidentifikasi meliputi tidak adanya jaringan kemitraan dengan lembaga lain. 
Rencana strategi yang dirumuskan dikelompokkan dalam empat bidang yaitu kurikulum, humas, kesiswaan, dan sarana prasarana. Strategi yang dirumuskan untuk peningkatan daya saing di bidang Kurikulum meliputi: 1) rekonstruksi reputasi sekolah melalui peningkatan prestasi akademik dan non akademik dan 2) mengembangkan kurikulum yang inovatif, berbasis pengalaman dengan dunia luar dan TI, 3) peningkatan kemampuan dan keahlian guru dan tenaga kependidikan di bidang TI, dan 4) menyusun program kewirausahaan sekolah. Strategi yang disarankan dalam bidang kesiswaan adalah 1) meningkatkan kualitas pelaksanaan program kegiatan sekolah dan 2) meningkatkan kedisiplinan siswa. Pada bidang Humas meliputi: 1) meningkatkan penggunaan TIdalam program promosi dan pemasaran sekolah, 2) memaksimalkan peran orang tua siswa, jaringan alumni, dan lembaga lain untuk pengembangan program kegiatan sekolah, 3) meningkatkan peran dan fungsi Komite Sekolah, dan 4) mengganti SMA mejadi SMK. Sedangkan strategi bidang sarana prasarana untuk meningkatkan daya saing sekolah adalah meningkatkan kualitas dan kuantitas sarana dan prasarana berbasis TI secara bertahap.

\section{Saran}

Berdasarkan hasil penelitian ini, saran yang dapat diberikan sebagai berikut:

1. Dalam upaya meningkatkan daya saing sekolah, Yayasan diharapkan selalu berperan aktif dan dan berani untuk mengambil keputusan untuk mengatasi permasalahan yang dihadapi oleh sekolah.

2. Kepala sekolah dapat mempertimbangkan untuk merumuskan visi baru sekolah dengan tujuan dan jangkauan waktu yang terukur serta melakukan komunikasi aktif dengan yayasan dan komite sekolah dalam imple- mentasi rencana strategis khususnya terhadap wacana strategi pendirian SMK.

3. Guru diharapkan selalu berkomitmen dan konsisten dalam melaksanakan upaya perbaikan prestasi sekolah melalui program kegiatan akademik dan non akademik. Guru dan staf diharapkan meningkatkan profesionalitas, kemampuan dan keahlian sesuai dengan perkembangan teknologi informasi.

4. Komite sekolah diharapkan selalu berkomunikasi dengan pihak sekolah dalam implementasi dan evaluasi rencana strategis.

\section{DAFTAR PUSTAKA}

Ahmad, H., \& Francis, A. 2007. Business Process Reengineering/: Critical Success Factors in Higher Education. Business Process Management Journal Vol. 13 N0.3 pp 451-469. doi:10.1108/ 14637150710752344.

Badan Pusat Statistik Kota Salatiga. 2011. Salatiga Dalam Angka Tahun 2011. Retrieved from http://salatigakota. bps.go.id/index.php?hal= publikasi_detil\&id=2

Belfield, C. R., \& Levin, H. M. 2002. The effects of competition between schools on educational outcomes: A review for the United States. Review of Educational research, 72(2), 279-341.

Binsardi,A., \& Ekwulugo, F. 2003. International marketing of British education: research on the students' perception and the UK market penetration. Marketing Intelligence \& Planning, 21(5), 318-327. doi:10.1108/ 02634500310490265

Bosetti, L. 2004. Determinants of school choice: understanding how parents choose elementary schools in Alberta. Journal of Education Policy Vol. 19, No. 4. 
Breen, H., \& Hing, N. 2012. Improving competitiveness through cooperation: Assessing the benefits of cooperative education partnerships in gaming management. UNLV Gaming Research \& Review Journal, 6(1), 5.

Casidy, R. 2013. The role of brand orientation in the higher education sector: a studentperceived paradigm. Asia Pacific Journal of Marketing and Logistics, 25(5), 803-820.

Chapleo, C. 2010. What defines "successful" university brands? International Journal of Public Sector Management, 23(2), 169-183.

Crainer, S., \& Dearlove, D. 2014. Thinkers 50 Strategy: The Art and Science of Strategy Creation and Execution. Mc Graw Hill Education.

Danim, S. 2006. Visi Baru Manajemen Sekolah: Dari Unit Birokrasi ke Lembaga Akademik. Jakarta: PT Bumi Aksara.

DeNisi, A. S., Hitt, M. A., \& Jackson, S. E. 2003. The knowledge-based approach to sustainable competitive advantage. Managing knowledge for sustained competitive advantage: Designing strategies for effective human resource management, 3-33.

Depperu, D., \& Cerrato, D. 2005. Analyzing international competitiveness at the firm level: concepts and measures. Qualderni del Dipartimento di Scienze Economiche e Sociali, Università Cattolica del Sacro Cuore-Piacenza, 32.

Dinas Pendidikan Kota Salatiga. (n.d.). Data Sekolah Kota Salatiga. Retrieved September 21, 2014, from http:// salatiga.siap.web.id/

Dinas Pendidikan Kota Salatiga. 2014. Penerimaan Peserta Didik Baru Kota Salatiga. Retrieved January 31, 2015, from salatiga.siap-ppdb.com
Gates, L. P. 2010. Strategic planning with critical success factors and future scenarios: An integrated strategic planning framework. (No. CMU/SEI-2010-TR037). CARNEGIE-MELLON UNIV PITTSBURGH PA SOFTWARE ENGINEERING INST.

Gross, K. 2004. Process Reengineering and Legal Education: An Essay on Daring to Think Differently. NYL Sch. L. Rev., 49, 435.

Haan, H. De, \& Yan, H. 2013. Competitive Advantage, What Does It Really Mean? In Democratizing Management EURAM 13th 2013. Istanbul, Turky.

Hakim, D. 2012. Pengembangan Pendidikan Kewirausahaan Berdasarkan Nilai-Nilai Budaya untuk Membentuk Daya Saing dan Karakter Bangsa. In Prosiding Seminas Competitive Advantage I(2).

Hawkins, R. J. 2002. Ten lessons for ICT and education in the developing world. The World Bank Institute.

Ireland, R. D., Hitt, M. A., \& Vaidyanath, D. 2002. Alliance Management as a Source of Competitive ADvantage. Journal of Management 28(3) 413-446.

Kazlauskaite, R., \& Buciuniene, I. 2008. The role of human resources and their management in the establishment of sustainable competitive advantage. Inzinerine Ekonomika-Engineering Economics, 5, 78-84.

Krismawintari, N. P. D. 2011. Faktor-faktor yang dipertimbangkan orang tua dalam memilih sekolah (Studi pada SMPK 1 Harapan Denpasar). Universitas Udayana.

Marginson, S., \& Wende, M. van der. 2007. Education To Rank or To Be Ranked: The Impact of Global Rankings in Higher. Journal of Studies in International Education 2007;11;306. 
Ogrean, C., \& Herciu, M. 2010. Globalization and the dynamics of competitiveness- a mulilevel bibliographical study. Studies in Business and Economics ,5.(1), 126-138.

Rahayu, A. 2010. Analisis Sumber Daya Sekolah dan Program Penciptaan Nilai dalam Meningkatkan Daya Saing Sekolah. Educationist Vol. IV No I.

Rahman, M. A. S. 2015. Daya Saing Tenaga Kerja Indonesia dalam Menghadapi Masyarakat Ekonomi ASEAN (MEA). eJournal Ilmu Hubungan Internasional, 2015, 3 (1): 117-130.

Rohrbeck, R. 2010. Harnessing a network of experts for competitive advantage: technology scouting in the ICT industry. $R \& d$ Management, 40(2), 169-180.

Sprawls, P. (n.d.). Re-Engineering The Educational Process. http://www. sprawls. org/RE/. Retrieved November 26, 2014, f rom www.sprawls.org

Srivastava, R. K., Fahey, L., \& Christensen, H. K. 2001. The resource-based view and marketing: The role of market-based assets in gaining competitive advantage. Journal of management, 27(6), 777-802.

Sugiyono. 2009. Metode Penelitian Pendidikan: Pendekatan Kuantitatif, Kualitatif, dan $R \& D$. Bandung: Alfabeta.

Tagalou, A., Massourou, V., \& Kuriakopoulou, K. 2013. ICT in Educational Proceedings, 3840-3846.
Tamandl, L., \& Nagy, D. 2013. Competitiveness Factor of Higher Education Institutions with Particular Respect to Hungarian Cities. In Real Corps 2013 20-23 May 2013.

Tinio, V. L. 2003. ICT in Education. United Nations Development ProgrammeAsia Pacific Development Information Programme.

Tjuana, A. 2012. Memberdayakan Komite Sekolah untuk Meningkatkan Mutu Layanan Pendidikan. Jurnal Uniera Volume I No 1.

Trim, P. R. 2003. Strategic Marketing of Further and Higher Educational Institutions: PartnershipArrangement and Centres of Entrepreneurship. The International Journal of Education Management 17/2 59-70.

Tunç, E. A. 2013. Reengineering Higher Education. Yüksekö£retim Dergisi 2013;3(I):48-52.

Utomo, P. 2014. Kesiapan Sumber Daya Manusia (Tenaga Kerja) Bidang Konstruksi di Indonesia Menghadapi Masyarakat Ekonomi ASEAN. QISTIE 7(2). 